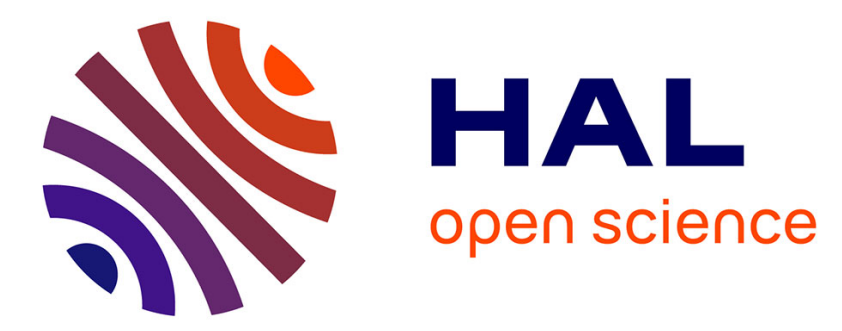

\title{
Individual and contextual socioeconomic disadvantages and car driving between 16 and 24 years of age: a multilevel study in the Rhône Département (France)
}

Idlir Licaj, Mohamed Mouloud Haddak, Pascal Pochet, Mireille Chiron

\section{- To cite this version:}

Idlir Licaj, Mohamed Mouloud Haddak, Pascal Pochet, Mireille Chiron. Individual and contextual socioeconomic disadvantages and car driving between 16 and 24 years of age: a multilevel study in the Rhône Département (France). Journal of Transport Geography, 2012, 22, pp.19-27. 10.1016/j.jtrangeo.2011.11.018 . halshs-00657323

\section{HAL Id: halshs-00657323 \\ https://shs.hal.science/halshs-00657323}

Submitted on 7 Jan 2012

HAL is a multi-disciplinary open access archive for the deposit and dissemination of scientific research documents, whether they are published or not. The documents may come from teaching and research institutions in France or abroad, or from public or private research centers.
L'archive ouverte pluridisciplinaire HAL, est destinée au dépôt et à la diffusion de documents scientifiques de niveau recherche, publiés ou non, émanant des établissements d'enseignement et de recherche français ou étrangers, des laboratoires publics ou privés. 
Manuscript auteur, référence : Licaj I., Haddak M., Pochet P., Chiron M. (2012), Individual and contextual socioeconomic disadvantages and car driving between 16 and 24 years of age: a multilevel study in the Rhône Département (France), Journal of Transport Geography, Vol. 22, pp. 19-27.

\section{Individual and contextual socioeconomic disadvantages and car driving between 16 and 24 years of age: a multilevel study in the Rhône Département (France)}

\section{Idlir Licaj ${ }^{13}$, Mouloud Haddak ${ }^{13}$, Pascal Pochet $^{23}$, Mireille Chiron ${ }^{13}$}

1 IFSTTAR (Institut Français des Sciences et Technologies des Transports, de l'Aménagement et des Réseaux), UMR T9405 (Umrestte), 25 avenue François Mitterrand, Bron F-69675; Université Lyon 1, France

2 LET (Laboratoire d'Economie des Transports), ENTPE - Université Lyon 2 - CNRS, UMR 5993, rue Maurice Audin, 69518 Vaulx-en-Velin Cedex, France

3 Université de Lyon

Corresponding author: Idlir Licaj

E-mail: $\underline{\text { idlir.licaj@gmail.com }}$ 


\begin{abstract}
This paper sets out to highlight and quantify the effect of individual and contextual deprivation on both access to a car driving licence and on actual driving of a car among young licence-holders in the Rhône département (France). The three stages by which adolescents and very young adults become autonomous with regard to driving have been subjected to multilevel analyses, using a Household Travel Survey: i) whether young persons participate in the early driving scheme at 16-17 years of age, ii) whether young persons of 18-24 years of age hold a driving licence, and iii) whether young licence-holders actually drive a car. At these three stages, social inequalities can be observed. This study highlights the considerable impact socioeconomic (individual but also contextual) factors and gender have on inequalities of access to car driving. Underprivileged groups suffer from disadvantages that accumulate at each stage (driving licence and car driving). The multilevel analysis of access to the car among young persons shows that considering the effects of the geographical context improves our understanding of travel inequalities.
\end{abstract}

Keywords: deprivation, driving license, car driving, car ownership, young, multilevel analysis, household travel survey.

\title{
1. Introduction
}

In car dependent societies, obtaining a driving licence is essential in order to gain the capacity for independent travel. It opens up the possibility for personal access to a car, which leads to higher travel speeds - at least outside the central or dense part of the cities - meaning that individuals can travel to a wider range of locations to perform activities within a given amount of time (Dupuy, 1999). A study conducted in three Canadian cities among poor or vulnerable groups has shown that the possession of a driving licence and a car increases the distances individuals in these groups cover, which may help to improve their access to urban "opportunities" (Morency et al., 2011). In a context in which the dispersion of activities, particularly in zones where accessibility without a car is difficult, for example, in periurban areas with poor public transport or in rural areas, not having a driving licence or access to a car can lead to problems of autonomy which increase social exclusion (for example, for the USA, Viry et al., 2009 and, for the United Kingdom, Hine and Mitchell, 2001; Lucas et al., 2006; Preston and Rajé, 2007; Shucksmith, 2004). The importance of transport conditions on job access has been studied extensively for the case of the United States (for a review, Blumenberg and Manville, 2004). In California, most of the low wage jobs are accessible by a 30 minute commute trip in a private vehicle (Blumenberg 
and Hess, 2003). Unlike public transport accessibility, the access to a car has a significant effect on job opportunity and employment stability (Cervero et al., 2002). More specifically for young adults, driving a car can be more or less indispensable depending on the location, the individual's car-dependency, the alternatives available in terms of public transport, and whether there are local jobs, services and shops. While in the centre of large cities, some young adults do not feel the need to take a driving test, this is nevertheless a very small group. In more car dependant areas, such as low density outskirts and rural areas, the possibility of driving a car is one of the basic skills and attributes required in order to enter the world of work and more generally successfully engage in the activities of daily life (Orfeuil, 2004, Le Breton, 2005).

In European countries such as the United Kingdom (Lucas et al., 2009) and France (Paulo, 2006, Mignot and Rosales-Montano, 2006), a household's access to a car is still linked to its income. Multi-car ownership is less common for low-income households than for wealthier households. Low-income households are also more frequently non-motorised in France (Nicolas et al., 2003) and in the United Kingdom (Lucas, 2004, Lucas et al., 2009). Likewise, in underprivileged areas, the percentage of car-owning households seems to be systematically lower, as has been observed in Scotland (Hine and Mitchell, 2003), and in Lyon in France (Haddak et al., 2010). In the United States too, household's access to a car remains still linked to its income despite widespread availability of cars (Lucas, 2004, Fol et al., 2007; Fol, 2009). At the national level, 36\% of the low income households had no car in the middle of the nineties, for $4 \%$ of the other households (Murakami and Young, 1997).

Few studies have dealt specifically with the issue of how social class or educational attainment affects the difficulty of obtaining a driving licence, with the exception of Priya and Uteng (2009) who examined non-European immigrants in three Norwegian cities. This study found that the difficulties low income immigrant populations have in meeting the financial cost of obtaining a driving licence followed by the subsequent cost of gaining access to a car make it harder for them to find work (Priya and Uteng, 2009). In France too, one can make the hypothesis that the conditions that apply for learning to drive and above all its financial cost would result in social inequalities with regard to access to driver training. The law lays down that learner drivers must spend at least 20 hours driving with an instructor. The average nation-wide is more like 28 hours of driving, and the average total cost of learning to drive was $€ 1500$ in 2007 (Lebrun et al., 2008), but this average figure conceals large disparities between regions and individuals. In particular, the difficulties experienced by young persons who are facing problems in social integration can mean that obtaining a licence costs them much more than the average amount (Bertand, 2005). Traditionally, conscription (followed by a twelve-month period of national service) provided the 
opportunity for many young men who came from underprivileged backgrounds or who had left school early to learn to drive and obtain a driving licence. The abolition of conscription in 2001 may also have made it more difficult for young men from underprivileged social backgrounds to obtain a driving licence (Lebrun et al., 2008).

In addition, while the minimum age for obtaining a car licence is 18, in France 16 and 17 year-olds can participate in the early driver training scheme (Apprentissage Anticipé à la Conduite - AAC), which includes a period in which the young driver is supervised by an adult in the passenger seat (over a minimum distance of $3000 \mathrm{~km}$ ) under conditions that are fixed by the driving school. This scheme increases young drivers' chances of passing their test the first time they take it and obtaining their licence early: $68 \%$ are in that situation, compared with $49 \%$ of those who do not take up the early training scheme in 2007. The global success rate to the licence test is 54\% (a proportion around the EU average) due to the difficulty of the practical test and to the lack of preparation of part of the candidates (Lebrun et al., 2008). However, the scheme was only taken up by $30 \%$ of those who took the test in 2010 (Muhlmann-Weill, 2010). Take-up of the scheme among the population is unevenly distributed socially because of its slightly higher cost and because underprivileged households have lower car ownership and fewer opportunities for accompanied driving (INSERR, 2007), although it is true that we lack detailed studies on this issue. Within this context, this paper sets out to highlight and quantify the effect of individual and contextual deprivation on both access to driving licence and on actual driving of a car among young licence-holders in the Rhône département. With this in mind, we have studied simultaneously the effect of individual factors (such as age, gender, parental income, household car ownership) and environmental factors (the extent to which the individual's residential location is central/urban or remote/rural, and the socio-economic level of the area). The three stages by which adolescents and very young adults become autonomous with regard to driving have been subjected to multilevel analyses: i) whether young persons participate in the early driving scheme at 16-17 years of age, ii) whether young persons of 18-24 years of age hold a driving licence, and iii) whether young licence-holders actually drive a car.

\section{Data and methodology}

\subsection{The 2005-2006 Household Travel Surveys on the Lyon urban district 2005-2006}

The Household Travel Survey (HTS) that we used was carried out between November 2005 and May 2006. The Lyon HTS is representative of the population of households living within the study boundary. This includes the Rhône Département, where the majority of the poorest urban 
zones are located, and which forms our study area.

The sample contained 2,246 persons between 16 and 24 years of age who were residents of the Rhône Département. Among them, 69\% lived with their parents, while and 31\% lived in their own household. Each individual of 16 years of age and over was asked if he/she had a driving licence. The possible answers were "yes", "no" or "accompanied driving and driving lessons".

In this study we have measured car driving on the basis of the individual's habitual car use on working days outside weekends and school holidays by means of a binary variable which distinguishes between individuals who drive a car, even infrequently, and those who report never driving.

The area covered by the HTS has been broken down into a number of sectors which provide the basis for sample stratification, the administration of the survey and the weighting of the data. These sectors were then divided into what we shall refer to as "small zones" which allow us to identify with a fair degree of accuracy individuals' residential, working or study locations and the origins and destinations of their trips.

\subsection{Individual and contextual socioeconomic indicators}

In addition to age and gender, the explanatory variables we have used in the study are the social and economic characteristics of the young people and their zone of residence. We have used a number of indicators to measure these characteristics:

- the variable that describes "status" within the household allows us to distinguish between young persons who live in their own household (i.e. who are the household reference person, the reference person's partner or another person, without parental link) from those who live in the same household as their parents or another reference person. We will say that the second group has the status of a child in the household. They accounted for $65 \%$ of the 18-24 year-olds. This explanatory variable was not used to investigate accompanied driving training among 16-17 year-olds, $98 \%$ of whom had the status of a child in the household.

- income per consumption unit $(\mathrm{CU})$ is the most precise indicator of the relative social positions of the households to which the young people belong. The number of household consumption units is calculated by giving 1 for the first adult, 0.5 for all other members aged of 14 and more and 0.3 for children under 14 (Hourriez and Ollier, 1997). More precisely, we have used the mean annual income quartiles per consumption unit of the 
household of the young persons between 16-24 years of age by creating 4 income classes ( $1^{\text {st }}$ quartile: income of less than $€ 10,902,2^{\text {nd }}$ quartile: income of between $€ 10,902$ and $€ 15,857,3^{\text {rd }}$ quartile: income of between $€ 15,857$ and $€ 21,578$, and $4^{\text {th }}$ quartile: income of more than $€ 21,578)$.

- household vehicle ownership (no car, one car, or two or more cars),

- the geographical position of the small zone of residence:

- the centre of the conurbation that includes the municipalities of Lyon and Villeurbanne, where the residential density is on average 11,143 inhabitants $/ \mathrm{km}^{2}$;

- the inner suburbs (adjacent municipalities to Lyon or Villeurbanne) with an average density of 4,191 inhabitants/ $\mathrm{km}^{2}$;

- the outer suburbs, i.e. other municipalities in "Greater Lyon", with an average density of 1,909 inhabitants $/ \mathrm{km}^{2}$;

- periurban or rural municipalities: municipalities outside Greater Lyon, mostly sparsely populated periurban municipalities, and occasionally rural municipalities with an average population density of 905 inhabitants $/ \mathrm{km}^{2}$.

- whether or not there is a ZUS (Zone Urbaine Sensible) in the small zone of residence ${ }^{1}$. We have paid particular attention to the effect of these four socioeconomic variables, two of which characterize the individuals or their household and two their residential context.

\subsection{The Rhône Département and the ZUS's}

The Rhône is a French Département with 1.7 million inhabitants in the Rhône-Alpes Region whose main urban centre is the Lyon's conurbation (1.2 million inhabitants). The Rhône Département contains 293 municipalities, 25 of which have one or more ZUS. At the time of the survey, a population of 192,000 lived in the ZUS (11.5\% of the département's total population) and they were spread over 30 ZUS. The unemployment rate was $22.4 \%$ in the Rhône's ZUS, compared with $11.4 \%$ in the Département as a whole. In addition, in the under 25 s year-old age group, individuals with no formal academic qualifications and single-parent families were over-represented in the ZUS: in the ZUS, the under 25 's accounted for $39.2 \%$ of the population,

\footnotetext{
1 "'Zones Urbaines Sensibles" (ZUS) are deprived areas which have been identified by the public authorities as priority targets for urban action. These areas are characterized by large apartment buildings or slum areas, a pronounced imbalance between the number of dwellings and the number of jobs, and low incomes. In addition, ZUS residents are more often in casual employment than those living in other areas.
} 
persons with no formal academic qualifications accounted for $33.3 \%$ and single-parent families accounted for $21.5 \%$, while the figures for the rest of the Département were respectively $33.0 \%$, $18.7 \%$, and $13.6 \%$ (INSEE, 2006).

This set of socioeconomic characteristics therefore means that living in a ZUS constitutes a good indicator of a deprived social environment.

However, the Household Travel Survey does not tell us whether the individuals were living in a ZUS or not, as in most cases the boundaries of the ZUS do not coincide with those of the small zones used in the HTS. However, the young persons lived in a small zone which either had or did not have one or more ZUS. The presence of a ZUS in a small survey zone provided us with the contextual socioeconomic indicators we used in this study. In the Rhône Département, there are 497 small survey zones and 55 of them contained all or part of a ZUS. Each small zone contained an average of 2,923 inhabitants of over 4 years of age.

HTS zones including ZUS are comparatively well located. They are concentrated around the sites of the old big local industries, towards the East of Lyon's conurbation. We qualified as underprivileged zones, HTS zones including 5\% of their territory at the very least in ZUS, after having tested other thresholds $(10 \%, 15 \%, 20 \%, 35 \%$ and 50\%). The raw associations between the three variables under study (accompanied driving course, driving licence, actual car driving) and the different thresholds of underprivileged small zones were always significant and the Cramer's V indicator was similar between the different thresholds. Most of these "small zones with a ZUS" are underprivileged ones, some of them being, at least, contiguous and very close to a deprived zone. The presence of such tiny part (5\%) of the territory in ZUS is therefore a relevant indicator of an underprivileged territorial context. The average family income (per CU) in the zones with a ZUS was $€ 16,900$ per year with a quartile interval of $[€ 16,500-17,200]$ while it stood at $€ 21,600$ per year in the zones without a ZUS, with a quartile interval that was disjoint from the previous one of $[€ 21,400-21,800]$. Using this sociogeographical indicator thus allows us to consider urban contexts which are contrasting with regard to the incomes of their residents.

\subsection{Analyses}

We have attempted to quantify the effect of individual and contextual socioeconomic factors on:

- learning to drive a car in the case of 16-17 year-olds, i.e. accompanied driving,

- holding a driving licence or taking driving lessons in the case of 18-24 year-olds,

- customary or exceptional driving of a car in the case of young driving licence holders. 
We have investigated these three topics by applying multilevel logistical regression models in which the small zone of residence was the contextual unit. The reason for this choice is that multilevel models are better able to take into account the hierarchical structure of the data (i.e. individual and contextual characteristics) than usual logistic regression models because the latter underestimate the standard deviation of the parameters of contextual effects (Gelman and Hill, 2004; Witte et al., 2000). Individuals were thus to be found at the first level, and are then nested into their respective small zones at the second level. In addition, one of the most important assumptions made in usual regression analysis is the independence of individual measures. This assumption is violated in presence of multilevel data. People from the same area may be more similar to each other in relation to their mobility status than to people from other areas. The advantage of using multilevel modelling is that it takes the hierarchical structure of the data by specifying random effects of each level of the data and thus results in a more conservative inference for the area effect.

Multilevel models thus show whether the differences that are observed between small zones are due to a confusion effect arising from the fact that the individuals who live in the zones with a ZUS are underprivileged or if the small zone itself has a specific effect (Diez Roux, 2004). We have used the SAS Glimmix procedure (version 9.2) and assumed a normal distribution for the random effects. The GLIMMIX procedure fits statistical models to data with correlations or non constant variability and where the responses were not normally distributed like those analysed in this study. These models are known as generalized linear mixed models (SAS Institute Inc, 2008).

As a rule, the between-zones variation is reduced as explanatory factors are added to the model. The scale of this reduction allows us to perceive the extent to which different factors explain this variance.

For this analysis, five multilevel models were fitted taking into account the small zone (sometimes, including the small zone effect). To begin with, we applied an empty model (Model 1 baseline); it does not include any explanatory variable but only disentangle variability at the various levels. This served to observe the proportion of the variance that can be attributed to the contextual level (small zone). The empty model contained no other explanatory variable. Next, in Model 2, raw odds ratios were obtained for individual variables by computing a specific model for each of them with no other covariate. Model 3 included all the individual variables, and the contextual variables were introduced stepwise in Model 4. Last, all the individual and contextual variables were added simultaneously in Model 5.

The $\log$ likelihood model fit $(-2 \log \mathrm{L})$ was not presented, because, as a rule, its value is not 
reliable in logit multilevel models (Snijders and Bosker, 1999). For each regression model, the significance of the between-zone variation was tested with the Wald chi-squared statistic (1 degree of freedom) (Rasbah et al., 2004).

In order to examine access to a driving licence and car driving, we fitted a sixth full model without the car ownership variable, as household car ownership can be both the cause and the consequence of the children in a household who are of age of holding a driving licence. In addition, this variable was strongly correlated with household income and whether or not there was a ZUS in the small zone of residence. For example, $22.6 \%$ of young people in low income households (Q1) have two cars, whereas they are $79.3 \%$ in the high income bracket (Q4). For each of the multilevel models, we tested the interactions between whether the small zone was with or without a ZUS and the variable that describes the geographic position of the small zone, the number of cars owned by the household, and the household's income per consumption unit. The collinearity between the independent variables in regression models was tested with the variance inflation factors (VIF).The VIF values were overall under 4.0 (with slightly higher values - not exceeding 5.5 - for household income per UC and car ownership), suggesting that multicollinearity was not a severe problem in these regression models.

\section{Results}

\subsection{Car ownership in the young person's households}

Of the 2,246 young individuals of the sample, $15 \%$ belonged to a household without a car, $35 \%$ to a household with one car, and the other half (50\%) to a multi-car owning household. The distribution of the car ownership variable was very different in the group that consisted of young people who were living with one or both of their parents or their legal guardian (69\% of the total) and the group who were the household reference person or reference person's partner: only $4 \%$ of the first group lived in a carless household compared with $37 \%$ of the young people who were the reference person in their household.

\subsection{Access to accompanied driving from 16-17 years of age}

Our analysis covered 573 persons in the sample who were of 16 or 17 years of age. At the time of the survey, $22.1 \%$ of this group were taking an accompanied driving course. Even though the univariate association between gender and access to accompanied driving was not significant, we included gender in the multivariate logistical model in order to be consistent with the following 
analyses (access to driving licence and actual driving). None of the 16-17 year-olds taking an accompanied driving course belonged to a carless household, which explains our decision to measure the number of cars by means of a variable with two modalities, namely "one car" and " 2 or more cars". Besides, the main differences appear between the multi motorised households and the other ones. The interaction between income and the type of zone of residence was not significant. The zone of residence (with or without ZUS) as well as its geographical position did not have any significant impact on the access to accompanied driving scheme. Table 1 presents individual and contextual variables odds ratios with $95 \%$ confidence intervals for accompanied driving.

Table 1: Determinants of accompanied driving among 16-17 year-olds ( $n=573$ young persons from 244 small zones)

\begin{tabular}{|c|c|c|c|c|c|}
\hline & $\begin{array}{c}\text { Model 1 } \\
\text { Empty }\end{array}$ & $\begin{array}{c}\text { Model } 2 \\
\text { Raw OR* for the } \\
\text { individual } \\
\text { variables }\end{array}$ & $\begin{array}{c}\text { Model } 3 \\
\text { Adjusted OR for } \\
\text { the individual } \\
\text { variables }\end{array}$ & $\begin{array}{c}\text { Model } 4 \\
\text { Adjusted OR for } \\
\text { the contextual } \\
\text { variables }\end{array}$ & $\begin{array}{c}\text { Model } 5 \\
\text { (full) } \\
\text { Adjusted OR for } \\
\text { all the variables }\end{array}$ \\
\hline \multicolumn{6}{|l|}{ Gender } \\
\hline $\begin{array}{l}\text { Men } \\
\text { Women }\end{array}$ & & $\begin{array}{l}0.92[0.60-1.41] \\
1\end{array}$ & $\begin{array}{l}0.91[0.59-1.41] \\
1\end{array}$ & & $\begin{array}{l}0.95[0.62-1.48] \\
1\end{array}$ \\
\hline $\begin{array}{l}\text { Household } \\
\text { income per CU } \\
\text { Q1 } \\
\text { Q2 } \\
\text { Q3 } \\
\text { Q4 }\end{array}$ & & $\begin{array}{l}0.21[0.09-0.46] \\
0.48[0.27-0.87] \\
0.57[0.34-0.95] \\
1\end{array}$ & $\begin{array}{l}\mathbf{0 . 3 3}[\mathbf{0 . 1 5 - 0 . 7 7 ]} \\
0.65[0.35-1.19] \\
0.62[0.37-1.04] \\
1\end{array}$ & & $\begin{array}{l}\mathbf{0 . 4 0}[\mathbf{0 . 1 7 - 0 . 9 3}] \\
0.73[0.39-1.37] \\
0.70[0.41-1.20]\end{array}$ \\
\hline $\begin{array}{l}\text { Car ownership } \\
0 \text { or } 1 \text { car } \\
2 \text { or more cars }\end{array}$ & & $\begin{array}{l}\mathbf{0 . 3 0}[\mathbf{0 . 1 8 - 0 . 5 1}] \\
1\end{array}$ & $\begin{array}{l}0.39[0.22-0.68] \\
1\end{array}$ & & $\begin{array}{l}0.40[0.23-0.72] \\
1\end{array}$ \\
\hline \multicolumn{6}{|l|}{ Random effects } \\
\hline $\begin{array}{l}\text { Between-zones } \\
\text { variation } \\
\text { /standard } \\
\text { deviation }\end{array}$ & $0.41 / 0.26$ & - & $0.20 / 0.25$ & $0.23 / 0.25$ & $0.19 / 0.25$ \\
\hline $\begin{array}{l}\text { Chi square Wald } \\
\text { test** }\end{array}$ & 2.49 & & 0.64 & 0.85 & 0.58 \\
\hline \multicolumn{6}{|c|}{ Contextual variables that are constant within the zone } \\
\hline & & & & OR & OR \\
\hline $\begin{array}{l}\text { Small zone of } \\
\text { residence } \\
\text { With a ZUS } \\
\text { Without a ZUS }\end{array}$ & & & & $\begin{array}{l}0.37[0.19-0.72] \\
1\end{array}$ & $\begin{array}{l}0.56[0.28-1.11] \\
1\end{array}$ \\
\hline $\begin{array}{l}\text { Zone of residence } \\
\text { Periurban or rural } \\
\text { Outer suburbs } \\
\text { Inner suburbs } \\
\text { Centre }\end{array}$ & & & & $\begin{array}{l}0.89[0.49-1.61] \\
0.63[0.34-1.17] \\
0.53[0.25-1.11] \\
1\end{array}$ & $\begin{array}{l}0.81[0.43-1.52] \\
0.56[0.29-1.06] \\
0.62[0.29-1.32] \\
1\end{array}$ \\
\hline
\end{tabular}

* OR: Odds Ratio; bolt print indicates a significant association between the outcome and the dependent variable to the $95 \%$ confidence level. $* *$ For risk $\alpha=5 \%$ significance level, the between-zone variation is considered as significant when Wald Chi-square test is greater than 3.84 . 
The first model, Model 1 (empty), showed whether access to accompanied driving for 16 to 17 year-olds varied from one small zone to another (Table 1). These between-zones variations were not statistically different from 0 (Wald test $<3.84$ ), which indicates that there were not spatial disparities in accompanied driving between the 244 small zones (Table 1). In this case, the use of a multilevel logistical model was not indispensable. Nevertheless, in order to be consistent with the analyses presented in other parts of this paper, we used multilevel models to estimate the individual and contextual parameters.

Model 2 showed the univariate impact of the individual variables, and highlighted that access to accompanied driving increased with family income per CU. Likewise, young persons who belonged to households with only one or no car had much less access to accompanied driving than young persons living in multi-car owning households. The between-zones variation as estimated by the multilevel model fell by approximately $50 \%$ when individual factors were added (Model 3). This drop in between-zone variance showed that a considerable proportion of the contextual variability of the probability of accessing accompanied driving was due to differences in the individual characteristics of those living in the small zones. Model 4 showed that when the geographical effect of the zone of residence was controlled for, the young persons from small zones with a ZUS undertook accompanied driving less than those from small zones without a ZUS. In Model 5 (Table 1), when we controlled the effect of contextual variables and other individual variables, household car ownership and income were significantly associated with accompanied driving: the young persons from a household with only one or no car had lower access to accompanied driving than those who lived in a multi-car owning household ( $\mathrm{OR}=0.40)$. Likewise, the young persons with the lowest family income per CU had lower access to accompanied driving than those with the highest income $(\mathrm{OR}=0.40)$. The between-zones variation fell still further, reaching 0.19 . The fact that the small zone contextual factor was no longer significant when we moved from Model 4 to Model 5 led to the conclusion that contextual differences in learning to drive (less accompanied driving in small zones with a ZUS) were due to a composition effect arising from differences in the sociodemographic and social structure of the population in different zones rather than the contextual characteristics of the place of residence.

\subsection{Access to a driving licence among 18 to 24 year-olds}

Of the 1,673 18 to 24 year-olds in the sample, $30 \%$ did not hold a driving licence. At the age of $18,37 \%$ of men and $35 \%$ of women held a driving licence, and this proportion exceeded two-thirds by 20 years of age ( $71 \%$ among men, $68 \%$ among women). The gender difference peaked at the age of 24: the rate of driving licence holding continued to rise among men and 
reached $92 \%$ at 24 years of age while it failed to rise above $77 \%$ in the case of women. Table 2 sets out the results from the multilevel study of those who hold a driving licence or take driving training $(70.1 \%$ of the total).

Table 2: Determinants of driving licence access (licence holders or trainee drivers) among 18-24 year-olds (342 small zones)

\begin{tabular}{|c|c|c|c|c|c|c|c|}
\hline & $n$ & $\begin{array}{c}\text { Model 1 } \\
\text { Empty } \\
\text { between-z } \\
\text { one } \\
\text { variation }\end{array}$ & $\begin{array}{c}\text { Model } 2 \\
\text { Raw OR* for } \\
\text { the individual } \\
\text { variables }\end{array}$ & $\begin{array}{c}\text { Model } 3 \\
\text { Adjusted OR for } \\
\text { the individual } \\
\text { variables }\end{array}$ & $\begin{array}{c}\text { Model } 4 \\
\text { Adjusted OR for } \\
\text { the contextual } \\
\text { variables }\end{array}$ & $\begin{array}{c}\text { Model } 5 \\
\text { (full) } \\
\text { Adjusted OR for } \\
\text { all the variables }\end{array}$ & $\begin{array}{c}\text { Model } 6 \text { (full) } \\
\text { Without the } \\
\text { adjusted OR } \\
\text { for the car } \\
\text { ownership } \\
\text { variable }\end{array}$ \\
\hline \multicolumn{8}{|l|}{ Gender } \\
\hline Men & 810 & & $1.45[1.16-1.81]$ & $1.49[1.17-1.91]$ & & $1.48[1.16-1.90]$ & $1,43[1,13-1,81]$ \\
\hline Women & 863 & & 1 & 1 & & 1 & 1 \\
\hline \multicolumn{8}{|l|}{ Age } \\
\hline $18-20$ years & 761 & & $0.44[0.35-0.55]$ & $0.40[0.31-0.52]$ & & $0.39[0.30-0.51]$ & $0,39[0,31-0,50]$ \\
\hline 21-24 years & 912 & & 1 & 1 & & 1 & 1 \\
\hline \multicolumn{8}{|l|}{ Status in household } \\
\hline Child & 1088 & & $0,93[0,73-1,19]$ & $0.39[0.27-0.54]$ & & $0.41[0.28-0.58]$ & $0,92[0,69-1,23]$ \\
\hline $\begin{array}{l}\text { Other (reference person, } \\
\text { partner, other) }\end{array}$ & 585 & & 1 & 1 & & 1 & 1 \\
\hline \multicolumn{8}{|l|}{$\begin{array}{l}\text { Income*Zone with or } \\
\text { without a ZUS }\end{array}$} \\
\hline Q1* Zone with a ZUS & 190 & & $0.16[0.10-0.26]$ & $0.36[0.21-0.61]$ & & $0.40[0.23-0.68]$ & $0.16[0.10-0.26]$ \\
\hline Q2 *Zone with a ZUS & 122 & & $0.21[0.13-0.34]$ & $0.36[0.20-0.63]$ & & $0.39[0.22-0.69]$ & $0.22[0.13-0.37]$ \\
\hline Q3 *Zone with a ZUS & 75 & & $0.99[0.48-2.02]$ & $1.24[0.57-2.68]$ & & $1.34[0.62-2.90]$ & $1.11[0.53-2.32]$ \\
\hline Q4 *Zone with a ZUS & 45 & & $0.88[0.37-2.09]$ & $0.82[0.33-2.04]$ & & $0.84[0.34-2.08]$ & $0.86[0.36-2.08]$ \\
\hline Q1 *Zone w/out a ZUS & 291 & & $0.34[0.23-0.51]$ & $0.67[0.42-1.05]$ & & $0.67[0.24-1.08]$ & $0.31[0.21-0.48]$ \\
\hline Q2 *Zone w/out a ZUS & 310 & & $0.51[0.34-0.76]$ & $0.68[0.44-1.05]$ & & $0.69[0.45-1.07]$ & $0.47[0.31-0.71]$ \\
\hline Q3 *Zone w/out a ZUS & 315 & & $0.56[0.38-0.84]$ & $0.62[0.41-0.96]$ & & $0.63[0,41-0.96]$ & $0.55[0.37-0.83]$ \\
\hline Q4 *Zone w/out a ZUS & 325 & & 1 & 1 & & 1 & 1 \\
\hline \multicolumn{8}{|l|}{ Car ownership } \\
\hline No car & 270 & & $0.14[0.10-0.19]$ & $0.08[0.05-0.12]$ & & $0.07[0.04-0.11]$ & \\
\hline One car & 531 & & $0.34[0.26-0.45]$ & $0.29[0.21-0.39]$ & & $0.28[0.20-0.38]$ & \\
\hline Two or more cars & 872 & & 1 & 1 & & 1 & \\
\hline \multicolumn{8}{|c|}{ Random effects (intercept) } \\
\hline $\begin{array}{l}\text { Between-zones } \\
\text { variation/standard } \\
\text { deviation }\end{array}$ & & $0.32 / 0.09$ & & $0.32 / 0.11$ & $0.30 / 0.09$ & $0.27 / 0.11$ & $0.21 / 0.10$ \\
\hline Chi square Wald test*** & & 12.64 & & 8.46 & 11.11 & 6.02 & 4.41 \\
\hline \multicolumn{8}{|c|}{ OR for contextual variables that are constant within the zone } \\
\hline \multicolumn{8}{|l|}{$\begin{array}{l}\text { Geographical position } \\
\text { of the zone }\end{array}$} \\
\hline Periurban or rural & 335 & & & & $1.84[1.27-1.25]$ & $0.92[0.60-1.43]$ & $1.69[1.45-2.49]$ \\
\hline Outer suburbs & 416 & & & & $1.36[0.96-1.93]$ & $0.70[0.46-1.07]$ & $1.24[0.85-1.81]$ \\
\hline Centre & 588 & & & & 1 & 1 & 1 \\
\hline
\end{tabular}

* OR: Odds Ratio; bolt print indicates a significant association between the outcome and the dependent variable to the $95 \%$ confidence level. ** For risk $\alpha=5 \%$ significance level, the between-zone variation is considered as significant when Wald Chi-square test is greater than 3.84 .

The interactions between whether the small zone was with or without a ZUS and the geographical position of the zone of residence or the number of vehicles owned by the household were not 
significant. However, there was a significant interaction between whether the small zone was with or without a ZUS and the family income per CU ( $\mathrm{p}=0.0028)$. The relationship between the small zone with or without a ZUS and the outcome varies according to the level of income per CU. To study the effect of these two variables, including their interaction, we fitted a model with a variable crossing "Income" with "Zone of residence".

The between-zones variation in the empty model was statistically different from 0 (Wald test > 3.84), which means that there were differences between the 342 zones as regards driving licence holding (Table 2). In Model 2 driving licence holding was lowest among the young persons from households in the first two income quartiles living in a zone with a ZUS. In zones without a ZUS, driving licence access rose with income. Likewise, young persons from households with only one car and those from non-motorised households had a lower rate of driving licence holding than young persons from multi-car owning households. After the simultaneous addition of "individual" characteristics to Model 3, the between-zones variation was still significantly greater than 0 . While adding the household car ownership variable increased the between-zones variation, the other variables had the opposite effect, reducing it. The effects of the different variables on the between-zones variation therefore cancelled each other out when we moved from the empty model to Model 3. When we controlled for the effect of the other variables in Model 3, those young persons who lived with their parents had lower driving licence holding, while if we considered the raw effect, the "status in the household" variable was not significant. Likewise, the young persons from households in the first two income quartiles living in a small zone with a ZUS always held a driving licence less often than high income young persons living in a small zone with a ZUS. In addition, the young persons from households with only one or no car also less often held a driving licence than those from multi-car owning households. The effect of gender was unchanged. Adding the contextual variable "geographical position" to Model 4 slightly reduced between-zones variation. Access to a driving licence is more important in rural areas. However, the geographical position of the small zone of residence explains only a small proportion of the contextual variations in access to a driving licence. Still with regard to Model 4 , driving licence holding increased with distance from the centre of the conurbation. The proportion of young persons taking the driving test was higher among those living in rural areas than among those living in the centre of the conurbation (Lyon and Villeurbanne). When we controlled for the effect of all the variables (Model 5, full), we observed that between-zones variation was slightly lower than in the case of the empty model. In all cases this variation was statistically different from 0. All other things being equal, Model 5 shows that young men more often held a driving licence than young women. Those young people who lived with their parents less often held a 
driving licence than the others. The same applies to 18-20 year-olds compared with 21-24 yearolds. Furthermore, fewer of the least privileged young persons (the first two income classes or those who lived in a small zone with a ZUS) held a driving licence, and the same applied to young persons who lived in a household with only one or no car. Last, driving licence holding was lower among young persons living in the inner suburbs than those living in the centre. However, in the case of periruban or rural zones, once we controlled for random inter-zone variations and individual variations, we were not able to say whether access to the driving licence was higher in rural zones.

When the car ownership variable was withdrawn from the full model (Model 6), the between-zones variation was reduced, but it still remained significant (Table 2). The effect of age and gender were similar to those estimated by Model 5, but the effect of "status in the household" was no longer significant. In this model too, it was among the most underprivileged young people (with low incomes in class 1 and 2 and living in a small zone with a ZUS) that holding a driving licence was lowest.

\subsection{Driving a car}

The study of driving a car related to the 1,070 young persons of between 18 and 24 years of age in the sample who held a driving licence. Of this group, 955 (89.2\%) reported driving a car. The interactions between the socioeconomic level of the small zone (with or without a ZUS) and income on the one hand and the geographical position of the location of residence on the other were not significant.

In the empty model, the between-zones variation was significantly different from 0 (Table 3 ). Model 2, which dealt with the univariate effects of individual variables, showed that young people with the status of "child" within the household more frequently drove a car. In contrast, driving was rarer among young persons with low income (first quintile) and for young people living in a household with one car and for those with no car. When the individual variables were added simultaneously in Model 3, the between-zones variation fell considerably and ceased to be significantly different from 0 . This means that a considerable proportion of the geographical variability with regard to car driving among young people was due to differences in the composition of small zones in terms of individual characteristics. When we controlled for the other individual variables in Model 3, the young person's "status" in the household and the household's income per CU were no longer associated with driving a car. However, the effect of the household car ownership variable was similar to that observed in Model 2: young persons 
living in a household with only one or no car were less often drivers than those living in households with two or more cars.

Table 3: Determinants of car driving among 18-24 year-old driving licence holders (307 small zones)

\begin{tabular}{|c|c|c|c|c|c|c|c|}
\hline & $n$ & $\begin{array}{l}\text { Model } 1 \\
\text { Empty } \\
\text { between- } \\
\text { zone } \\
\text { variatio } \\
n\end{array}$ & $\begin{array}{l}\text { Model } 2 \\
\text { Raw OR } \\
\text { the individual } \\
\text { variables }\end{array}$ & $\begin{array}{l}\text { Model } 3 \\
\text { Adjusted OR } \\
\text { for the } \\
\text { individual } \\
\text { variables }\end{array}$ & $\begin{array}{l}\text { Model } 4 \\
\text { Adjusted OR } \\
\text { for the } \\
\text { contextual } \\
\text { variables }\end{array}$ & $\begin{array}{l}\text { Model } 5 \\
\text { (full) } \\
\text { Adjusted OR } \\
\text { for all the } \\
\text { variables }\end{array}$ & $\begin{array}{l}\text { Model 6 (full) } \\
\text { Without the } \\
\text { adjusted OR } \\
\text { for the car } \\
\text { ownership } \\
\text { variable }\end{array}$ \\
\hline \multicolumn{8}{|l|}{ Gender } \\
\hline Men & 548 & & $1.00[0.67-1.51]$ & $1.02[0.65-1.61]$ & & $1.02[0.64-1.61]$ & $0.88[0.57-1.36]$ \\
\hline Women & 522 & & 1 & 1 & & 1 & 1 \\
\hline \multicolumn{8}{|l|}{ Age } \\
\hline $18-20$ years & 365 & & $0.86[0.56-1.32]$ & $0.69[0.42-1.12]$ & & $0.66[0.40-1.09]$ & $0.63[0.39-1,00[$ \\
\hline 21-24 years & 705 & & 1 & 1 & & 1 & 1 \\
\hline \multicolumn{8}{|l|}{ Status in household } \\
\hline Child & 656 & & $2.71[1.75-4.19]$ & $0.69[0.37-1.29]$ & & $0.69[0.36-1.32]$ & $1.92[1.14-3.22]$ \\
\hline $\begin{array}{l}\text { Other (reference person, } \\
\text { partner, other) }\end{array}$ & 414 & & 1 & 1 & & 1 & 1 \\
\hline \multicolumn{8}{|l|}{ Income per $\mathrm{CU}$} \\
\hline Q1 & 251 & & $0.29[0.16-0.52]$ & $1.01[0.51-2.01]$ & & $1.12[0.56-2.24]$ & $0.43[0.23-0.80]$ \\
\hline Q2 & 267 & & $0.74[0.39-1.42]$ & $1.25[0.63-2.51]$ & & $1.32[0.65-2.69]$ & $0.85[0.43-1.65]$ \\
\hline Q3 & 270 & & $1.32[0.64-2.73]$ & $1.63[0.77-3.44]$ & & $1.68[0.79-3.57]$ & $1.35[0.65-2.80]$ \\
\hline Q4 & 282 & & 1 & 1 & & 1 & 1 \\
\hline \multicolumn{8}{|l|}{ Car ownership } \\
\hline No car & 113 & & $0.04[0.02-0.07]$ & $0.03[0.01-0.07]$ & & $0.03[0.01-0.08]$ & \\
\hline One car & 304 & & $0.37[0.21-0.64]$ & $0.32[0.17-0.60]$ & & $0.37[0.19-0.72]$ & \\
\hline Two or more cars & 653 & & 1 & 1 & & 1 & \\
\hline \multicolumn{8}{|c|}{ Random effect (intercept) } \\
\hline $\begin{array}{l}\text { Between-zones variation / } \\
\text { standard deviation }\end{array}$ & & $\begin{array}{l}0.85 / 0.2 \\
5\end{array}$ & & $0.27 / 0.28$ & $0,49 / 0,25$ & $0.22 / 0.30$ & $0.49 / 0.27$ \\
\hline Chi square Wald test** & & 11.56 & & 0.93 & 3.84 & 0.54 & 3.30 \\
\hline \multicolumn{8}{|c|}{ Contextual variables that are constant within the zone } \\
\hline & & & & & OR & OR & \\
\hline \multicolumn{8}{|l|}{ Zone of residence } \\
\hline With a ZUS & 227 & & & & $0.51[0.30-0.86]$ & $0.53[0.31-0.91]$ & $0.54[0.62-0.93]$ \\
\hline Sans ZUS & 843 & & & & 1 & 1 & 1 \\
\hline \multicolumn{8}{|l|}{ Municipality } \\
\hline Periurban or rural & 239 & & & & $5.38[2.52-11.5]$ & $1.69[0.73-3.92]$ & $3.68[1.67-8.12]$ \\
\hline Outer suburbs & 266 & & & & $4.02[2.03-7.98]$ & $1.21[0.54-2.67]$ & $2.45[1.16-5.17]$ \\
\hline Inner suburbs & 195 & & & & $2.15[1.16-4.00]$ & $0.77[0.39-1.55]$ & $1.50[0.78-2.89]$ \\
\hline Centre & 370 & & & & 1 & 1 & 1 \\
\hline
\end{tabular}

* OR: Odds Ratio; bolt print indicates a significant association between the outcome and the dependent variable to the $95 \%$ confidence level. $* *$ For risk $\alpha=5 \%$ significance level, the between-zone variation is considered as significant when Wald Chi-square test is greater than 3.84 .

When the contextual socio-economic variable "zone with or without a ZUS" and the sociogeographical variable were added to the multilevel logistical model (Model 4), the between-zones variation was lower than that obtained with the empty model, and was not significantly different from 0 . It should be noted that, proportionally, this reduction was lower than that observed with the addition of individual variables. When the geographical nature of the zone of residence and the between-zones variations were controlled for, Model 4 showed that car driving was less widespread among young persons living in zones with a ZUS (underprivileged). However, a higher proportion of young persons from periurban or rural areas, or the inner or outer 
suburbs, drove a car than those from the centre of the conurbation. When the effects of the other variables in the full model (Model 5) were controlled for, a further reduction compared with the previous models (Models 3 and 4 ) in between-zones variation was observed.

All other things being equal, fewer young persons drove among the young persons who were living in a household with no car or to a lesser degree, with only one car, and the young persons from small zones with a ZUS. Removing the car ownership variable from Model 6 (the full multivariate model) led to an increase in between-zones variation, which was nevertheless still not significant (Table 3). The 18-20 year olds were less often drivers than the 21-24 year olds, but the young persons with the status of child in the household were more often drivers than those not living with their parents. Judging from the odds-ratios, income behaves as a concave function, as the proportion of drivers was at a minimum at the extremes of income and a maximum for intermediary incomes. However, only the young persons in the lowest income group (class 1) were significantly less often drivers than the others. As in the case of Model 5, the young persons living in a small zone with a ZUS were less often car drivers than those living in a small zone without a ZUS. The geographical position of the municipality had a gradient effect on driving. The young persons from rural and periurban zones were more often drivers than those from Lyon and Villeurbanne.

\section{Discussion}

The Lyon HTS provides valuable information about the travel practices of the population of the Rhône Département and has provided the basis for a multilevel analysis of social inequalities by the simultaneous use of individual and social variables.

We do not have any information about car driving at weekends or during school holidays. However, among young French people, social inequalities have a greater impact on long distance travel, especially by car (summer holidays), than on local driving, on weekend driving than on weekday driving, on leisure trips than on daily trips. Individuals with low incomes tend to engage in leisure activities that are nearer their home than individuals with high incomes (Paulo, 2006). The differences in car driving that we observed between individuals with different levels of income and between individuals from privileged and underprivileged zones would probably have been greater if we had been able to study all the days of the year.

All other things being equal, living in a small zone with a ZUS is the outcome of negative externalities that are due to the accumulation of social inequalities. The introduction of contextual 
factors, i.e. living in a zone with or without a ZUS and the geographical position of the municipality of residence, does not lead to a marked change in the Odds Ratios. These contextual variables therefore contain different information that supplements that contained in the individual variables rather than just the same information. We can suggest two possible explanations for the effect of the contextual variables, and particularly that which states whether the small zone of residence has a ZUS or not. The first is that there are some explanatory variables to which we did not ascribe sufficient importance, or which we did not consider (because they were unavailable in our survey), and which are correlated with living in a small zone with a ZUS. Thus some features, such as having a parent out of work, belonging to a single-parent household or the household size, were not considered in the multivariate model due to their strong correlation to both income and motorisation.

The second is that we have clearly shown the existence of a "ZUS effect", as the principal individual determinants of car driving (and travel in general) have been considered. We tend to the view that the second is the case, but this needs to be confirmed by other multilevel studies.

Differences between men, and women are also observed in this study as far as holding licence rate is concerned. These gender differences in driving licence rate among the young adults are also observed at the national level in France (Robin, 2010) and in other European countries such as Spain (Cebollada, 2009), and UK (Knowles, 2006), and more precisely in Scotland (The Scottish Government, 2010) and Northern Ireland (NISRA, 2007).

For the three phenomena we have studied, the "household car ownership" variable has a very marked effect: if we control for the effect of the other variables, the young persons who live in a household with only one or no car are marked out by a lower incidence of early driver training, a lower rate of licence holding (and access to driver training) and a lower rate of car driving among licence holders. However, when we studied access to the driving licence and car driving, we analyzed the effect of the other factors, excluding car ownership. Removing this variable highlights the effect of individual and collective socioeconomic factors on access to a driving licence and the effect of individual factors on car driving. Car ownership clearly appears to act as an intermediate variable between social position and car use. In addition, increased use of other types of transport such as bicycles or motorized two-wheelers, and policies that aid the development of public transport could in future reduce the attractiveness of the driving licence in dense urban areas. Due the necessity for the young population, in many geographical contexts, to have a driving licence for social inclusion and job access, policy formulation should integrate both the individual and contextual dimensions of the difficulties to access to cars. 


\section{Conclusion}

We have observed that social inequalities add to each other: inequalities with regard to access to the driving licence followed by inequalities with regard to use of a car among licence-holders. These inequalities are both individual and contextual in nature. The multilevel analyses that we conducted which took account of all the individual and contextual variables have shown that:

- the socio-economic differences with regard to accompanied driver training among 16-17 year olds are predominantly due to individual factors: the lowest incidence of learning to drive before 18 years of age is found among young persons with low incomes living in a household with only one or no car. In this case the contextual differences with regard to driver training are the result of a composition effect arising from differences between the sociodemographic and social structure of the population from one zone to another.

- the socioeconomic differences as regards to possession of a driving licence are both individual and contextual in nature and there is an interaction between income and living in a small zone with or without a ZUS. Thus, young persons from the poorest families living in a small zone with a ZUS (underprivileged) are less often in possession of a driving licence than young persons with high incomes living in a zone without a ZUS. Furthermore, young persons living in the inner suburbs are less often in possession of a driving licence than those who live in the centre, in spite of the fact that they live in an environment where travel by modes other than the car is somewhat more difficult.

- inequalities with regard to driving a car among young driving licence holders are added to those that exist as regards holding a licence. All other things being equal (in particular individual characteristics), young driving licence holders living in small zones with a ZUS (underprivileged) are less often drivers than those living in small zones without a ZUS.

Another remarkable social inequality is that which exists between the genders: all other things being equal, the proportion of young men with a driving licence is significantly greater than the proportion of young women. This study highlights the considerable impact socioeconomic factors and gender have on inequalities of access to car driving. Underprivileged groups suffer from disadvantages that accumulate at each stage (driving licence and car driving). Even if we had no empirical indicators in the model to capture job access by mode of transport among the young, literature brings some evidence that this situation inevitably makes it harder for them to find work. Our multilevel analysis of access to the car among young persons shows that considering the 
effects of the geographical context improves our understanding of travel inequalities. To our knowledge no existing study in this area has applied this method.

\section{Acknowledgements}

We would like to thank SYTRAL (Syndicat Mixte des Transports pour le Rhône et l'Agglomération Lyonnaise) who are the owners of the Household Travel Survey for allowing us to use the survey data.

\section{References}

Bertrand, J.-M. (2005), Faciliter l'accès des jeunes au permis de conduire. Etude et propositions, Paris, Assemblée Nationale (parliamentary report) http://lesrapports.ladocumentationfrancaise.fr/BRP/054000133/0000.pdf.

Blumenberg, E., Hess, D. B. (2003), Measuring the role of transportation in facilitating the welfare-to-work transition: Evidence from three California counties, Transportation Research Record, 1859, 93-101.

Blumenberg E., Manville, M. (2004), Beyond the spatial mismatch: Welfare recipients and transportation policy, Journal of Planning Literature, 19(2), 182-205.

Cebollada, A. (2009), Mobility and labour market exclusion in the Barcelona Metropolitan Region, Journal of Transport Geography, 17(3), 226-233.

Cervero, R., Sandoval, O., Landis, J. (2002), Transportation as a stimulus of welfare-to-work, Journal of Planning Education and Research, 22(1), 50-63.

Church, A., Frost, M., Sullivan, K. (2000), Transport and social exclusion in London, Transport Policy, 7(3), 195-205.

Diez Roux, A. V. (2004), Estimating neighbourhood health effects: the challenges of causal inference in a complex world, Social Science and Medicine, 58(10), 1953-1960.

Dupuy, G. (1999), From the "magic circle" to "automobile dependence": measurements and political implications, Transport Policy, 6(1), 1-17.

Fol, S., Dupuy, G., Coutard, O. (2007), Transport policy and the car divide in the UK, the US and France: Beyond the environmental debate, International Journal of Urban and Regional Research, (31) $4,802-818$.

Fol, S. (2009), La mobilité des pauvres, Belin, Paris.

Gelman, A., Hill, J. (2007), Data analysis using regression and multilevel/hierarchical models, Cambridge University Press, New York.

Haddak, M., Pochet, P., Licaj, I. Vari, J., Randriantovomana E., Mignot D. (2010), Socio-spatial inequalities in road traffic risk and daily travel in adolescence, ID 01688 Selected Proceedings of $12^{\text {th }}$ World Conference on Transport Research Society.

Hine, J., Mitchell, F. (2001), Better for everyone? Travel experience and transport exclusion, Urban Studies, 38(2), 319-332.

Hine, J., Mitchell, F. (2003), Transport disadvantage and social exclusion: Exclusionary mechanisms in urban Scotland, Ashgate, Aldershot.

Hourriez, J.-M., Olier, L. (1997), Niveau de vie et taille du ménage: estimations d'une échelle d'équivalence, Economie et Statistique, 308, 65-94.

INSEE (2006), http://sig.ville.gouv.fr/Synthese/8269

INSERR (2007), Actes de la table ronde sur l'apprentissage anticipé de la conduite, Nevers (France), 12-13 mars 2007. 
Knowles R. D. (2006), Transport shaping space: differential collapse in time-space, Journal of Transport Geography, 14(6), 407-425.

Lebrun, D., Mathieu, M., Fraccaro, F. (2008), Audit sur la modernisation de l'apprentissage de la conduite et de l'examen du permis, Conseil Général des Ponts et Chaussées, report nº05621 for the MEDDAT \& French Ministry of Interior Affairs, Paris.

Le Breton, E. (2005), Bouger pour s'en sortir. Mobilité quotidienne et intégration sociale, Armand Colin, Paris.

Lucas, K. (2006), Providing transport for social inclusion within a framework for environmental justice in the UK, Transportation Research Part. A, 40(10), 801-809.

Lucas, K., Tyler, S., Christodoulou, G. (2009), Assessing the value of new transport initiatives in deprived neighbourhoods in the UK, Transport Policy, 16(3), 115-122.

Lucas, K. (ed.) (2004), Running on empty: Transport, social exclusion and environmental justice, The policy Press, University of Bristol.

Mignot, D., Rosales-Montano, S. (2006), Vers un droit à la mobilité pour tous: Inégalités, territoires et vie quotidienne, La Documentation française-PUCA, Paris.

Morency, C., Paez, A., Roorda, M. J., Mercado, R., Farber, S. (2011), Distance traveled in three Canadian cities: Spatial analysis from the perspective of vulnerable population segments, Journal of Transport Geography, 19(1), 39-50.

Muhlmann-Weill, M. (2010), Développer la pratique de la conduite accompagnée, http://www.permisdeconduire.gouv.fr/.

Murakami, E., Young, J. (1997), Daily travel by persons with low income, NPTS symposium, Bethesda, Maryland, October 29-31, http://npts.ornl.gov/npts/1995/Doc/LowInc.pdf.

NISRA-Northern Ireland Statistics \& Research Agency (2007), Draft Northern Ireland Travel Survey Report 20042006, Belfast, www.csu.nisra.gov.uk.

Paulo, C. (2006), Inégalités de mobilités: disparité des revenus, hétérogénéité des effets Thèse de Doctorat de Sciences Economiques. Lyon, Université Lyon 2.

Nicolas, J.-P., Pochet, P., Poimboeuf, H. (2003), Towards sustainable mobility indicators: Application to the Lyons conurbation, Transport Policy, 10(3), pp. 197-208.

Orfeuil, J.-P. (ed.) (2004), Transports, pauvretés, exclusions: pouvoir bouger pour s'en sortir, Ed. de l'Aube, La Tour d'Aigues.

Preston, J., Rajé, F. (2007), Accessibility, mobility and transport-related social exclusion, Journal of Transport Geography, 15(3), 151-160.

Priya, T., Uteng, A. (2009), Dynamics of transport and social exclusion: Effects of expensive driver's license, Transport Policy, 16(3), 130-139.

Rasbah, J., Steele, F., Browne, W., Prosser, B. (2004), A user's guide to MLwin, Centre for Multilevel Modelling, Institute of Education, University of London.

Robin, M. (2010), La motorisation des ménages continue de s'accroître au prix d'un vieillissement du parc automobile, La Revue du CGDD, «La mobilité des Français. Panorama issu de l'enquête nationale transports et déplacements $2008 »$, december, 99-121. http://www.developpement-durable.gouv.fr/IMG/pdf/Rev3.pdf.

Shucksmith, M. (2004), Social exclusion in rural areas: a review of recent research London, DEFRA.

Snijders, T., Bosker, R. (1999), Multilevel analysis: an introduction to basic and advanced multilevel modelling, Sage, London.

SAS Institute Inc (2008), The GLIMMIX Procedure, in SAS/STAT® 9.2 User's Guide. Cary, NC: SAS Institute Inc. http://support.sas.com/documentation/

The Scottish Government (2010), Scottish Transport Statistics n²9, Edinburgh, www.scotland.gov.uk.

Viry, G., Kaufmann, V., Widmer, E. D. (2009), Social integration faced with commuting: More widespread and less dense support networks, in Ohnmacht T., Maksim A., Bergman M. M. (eds), Mobilities and inequality, Ashgate, Farnham (UK)-Burlington (USA), 121-143.

Witte, J. S., Greenland, S, Kim, L. L., Arab, L. (2000), Multilevel modeling in epidemiology with GLIMMIX, Epidemiology, 11, 684-688. 